\title{
KONCEPT UMJERENOSTI U ISLAMU I NJEGOVA MANIFESTACIJA U FIKHU
}

\section{الوسطية في الإسلام : مفهومها ومظاهر ها}

\section{Sažetak}

Evidentno je da u islamu postoji koncept umjerenosti koji se očituje u svim segmentima islamske misli, od morala $i$ etike do društvenopravnog sistema. Čovjek, kao stvoreno i ograničeno biće, nesposoban je da uspostavi apsolutnu ravnotežu $i$ balans $u$ svom ovosvjetskom životu zbog svoje psihofizičke nemoći, svojih ličnih poriva, strasti $i$ stremljenja, objektivnih $i$ subjektivnih uticaja od strane društva, porodice, politike, nacije, rase, geografske pripadnosti, običaja itd., tako da svi sistemi koje je kreirao čovjek nose $i$ njegove ljudske nedostatke, što nam potvrđuje $i$ metoda historijske indukcije u čitanju povijesti. Nasuprot toga, vidimo jednu harmoniju i preciznost u Božijem stvaranju, kao $i$ u Njegovoj vjeri koju je kao sistem i program življenja poslao i objavio čovjeku.

Umjereni put u šerijatskom zakonodavstvu i društvenom pogledu ogleda se u ravnoteži $i$ balansu između slobode pojedinca $i$ prava društva, a naslanja se na razumijevanje parcijalnih šerijatskih tekstova u svjetlu općih intencija $i$ ciljeva Šerijata kojima neće proturječiti ili biti neovisni o njima.

Umjerena škola srednjeg puta proklamuje da Šerijat sadrži sve ono što je milost za ljude, što im olakšava $i$ pomaže u životu, smatrajući da mudžtehid mora imati znanstvene, intelektualne, moralne, fizičke $i$ druge predispozicije kako bi mogao na pravilan način pristupiti pozitivizaciji šerijatskih propisa gledajući na tekstove kur'ansko-hadiskih normi sa stajališta intencija i ciljeva Šerijata.

Ključne riječi: Koncept umjerenosti الوسطية, islamska pravna misao, parcijalni šerijatski tekstovi, mudžtehid, novi bukvalisti ili formalisti, novi mua'ttile ili reformisti, umjerena škola srednjeg puta, pravna norma, efektivni uzrok propisu...

\footnotetext{
${ }^{1}$ Islamski pedagoški fakultet u Bihaću
} 


\section{Uvod}

Mnogobrojni intelektualci i ulema - posebno je to izraženo u savremenom društveno-političkom angažmanu zemalja Golfa, Kuvajta ponaosob - tretiraju koncept umjerenosti u islamskoj misli kao jednu od glavnih odlika islamskog koncepta uopće, predstavljajući je i kao "التوازن",ravnotežu” i ,balans” između dvije suprotstavljenosti ili suprotnosti, tako da se ne izdvaja jedna od njih potiskujući drugu svojom biti, uticajem i ulogom. Primjere dviju krajnosti nalazimo u suprotnostima ili krajnostima kao što su: božansko i ljudsko; vječno i prolazno; materijalno i duhovno; sadašnje i eshatološko; prošlo i buduće; pojedinačno i kolektivno; realno i idealno; konstantno i nepromjenljivo; itd.

Što bi značio balans između ovih suprotnosti i krajnosti, osim da se njihov odnos uravnoteži pravdom i pravednim odnosom, kao što se navodi u suri Er-Rahman:

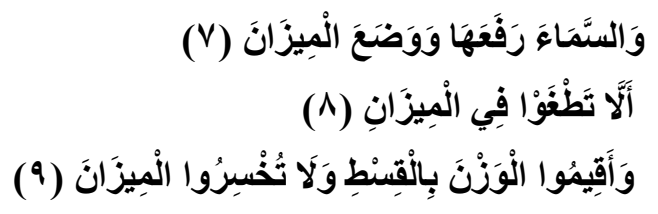

“... a nebo je digao. I postavio je ravnotežu i pravdu, /7/ da ne prelazite granice u mjerenju, /8/ $i$ pravo mjerite $i$ na tereziji ne zakidajte! /9/,'2

Manifestacija tog koncepta umjerenosti vidljiva je $\mathrm{u}$ svim oblastima sistema islamskog koncepta života i islamske vjere: u ideji i praksi; u odgoju i obrazovanju; u pravnom i političkom sistemu kao i u svim drugim oblastima življenja.

Što se tiče ibadeta i obredoslovlja, islam daje srednji umjereni put u vjeri, razlikujući se od budizma koji daje prednost moralu i moralnim principima čovjeka i od vjerskih sistema koji traže potpunu posvećenost asketizmu, zanemarujući ovosvjetske vrijednosti, kao što je slučaj u ideji kršćanskog asketizma i sveštenstva.

Dokaz tome je ajet koji govori o obavezi namaza džume, naređujući po završetku namaza, čak i u tom danu ili sedmičnom blagdanu, obavezu posvećivanja ovosvjetskim poslovima trgovine $\mathrm{i}$

\footnotetext{
${ }^{2}$ Kur'an:55:7-9.
} 
drugim ekonomskim djelatnostima, uz proglašavanje takvog koncepta „,spasonosnim”. Navodi se u suri El-Džumu'a:

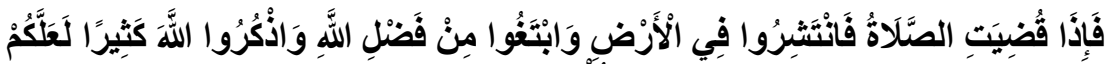

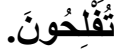

" A kad se molitva obavi, onda se po zemlji razidite i Allahovu blagodat tražite $i$ Allaha mnogo spominjite, da biste postigli što želite." $/ 10{ }^{\beta}$

Umjerenost $\mathrm{u}$ moralu i etici je između onih koji čovjekove moralno-etičke vrijednosti koje upoređuju sa bezgrješnim melekom, što je nedostižno za čovjeka, i onih koji te vrijednosti upoređuju sa životinjom i njenim osobinama, što je neprimjereno za stvorenje sa razumom. Jedni su otišli u krajnost, smatrajući čovjeka samo čistuncem i melekom, dok su drugi pretjerali i otišli u suprotnu krajnost, smatrajući čovjeka čistim zlom, kao što je šejtan - sotona. Islamski pogled je negdje između i tretira čovjeka kao stvorenje koje ima razum, ali i pohotu, životinjske strasti i instinkt, ali i duhovnu stranu, tako da je pripremljen za oba puta i mogućnosti dobra i zla, za opciju griješenja ili upute. Misija njegova džihada je borba sa svojim nefsom, očistiti se i biti bogobojažljiv, kao što to proklamuje Kur'an:
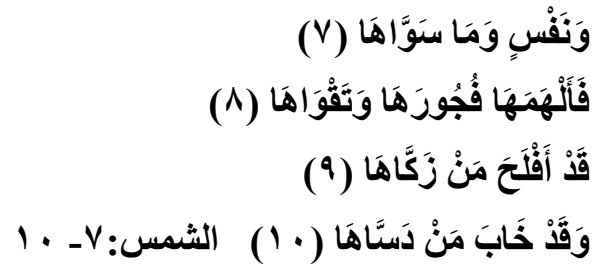

"...i duše i Onoga Koji je stvori", /7/ "pa je nadahnu da zna šta joj je grješenje a šta bogobojaznost", /8/ "uspjet će samo onaj ko je očisti" /9/"a bit će izgubljen onaj ko je na stranputicu odvodi!"/10/

Umjereni put u šerijatskom zakonodavstvu i društvenom pogledu ogleda se u balansu između slobode pojedinca i prava društva. Filozofska razmišljanja po pitanju slobode pojedinca i prava društva išla su iz jedne u drugu krajnost, završivši u krajnjoj konsekvenci na dva suprotstavljena tabora rigidne desnice i ljevice, odnosno kapitalizma i socijal-komunizma.

\footnotetext{
${ }^{3}$ Kur'an:62:10.

${ }^{4}$ Kur'an: 91:7-10.
} 
U islamu, prvo na šta se treba nasloniti fikh i šerijatsko-pravno zakonodavstvo u savremeno doba jeste razumijevanje parcijalnih šerijatskih tekstova u svjetlu općih intencija i ciljeva Šerijata, gdje će se njihovi propisi vezivati i usklađivati sa istinitim intencijama $i$ ciljevima Šerijata i neće im proturječiti ili biti neovisni o njima.

Tri su škole u savremenim fikhskim trendovima po pitanju ciljeva i intencija Šerijata.

1. Škola koja se drži parcijalnih tekstova sa bukvalnim nekritičkim razumijevanjem, bez traganja za ciljevima koje je Zakonodavac htio priskrbiti tom normom. Ovi الحَرْفيون ili formalisti, bukvalisti su grupa koju šejh El-Karadavi naziva novi bukvalisti koji su nasljednici starih bukvalista. Oni odbijaju traganje za efektivnim uzrokom propisa ili da se propis vezuje za bilo kakvu mudrost, cilj ili intenciju, ne dozvoljavaju analogiju, uz obrazloženje da je Uzvišeni Allah mogao da nam naredi ono što je zabranio, i obratno, pa čak je mogao i da nam naredi širk i nevjerovanje, a zabrani monoteizam. Od starih bukvalista su naslijedili formalizam i dekadentnost, a zanemarili intelektualnu širinu koju su stari učenjaci zahirijskog mezheba posjedovali, kao i veliko poznavanje hadisa i predaja.

2. Druga škola je upravo suprotnost prvoj, jer uzima u obzir ciljeve i intencije Šerijata gledajući na duhovnu stranu vjere, iako pada u drugu, još goru krajnost, zapostavljajući i zanemarujući parcijalne kur'anske tekstove i norme, kao i vjerodostojne hadise tvrdeći da je vjera suština جوهر , شكل a ne samo oblik , حقة , istina , ne samo slika i oblik صورة, ali ako im se suprostavi jasan tekst, onda se vade i pravdaju, odbijanjem, čak i vjerodostojnog sunneta - ustvari oni i ne razlikuju vjerodostojno od slabog, a mijenjaju i kur'anska značenja, držeći se nejasnih ajeta. Nazivaju se reformistima أدعياء) (التجديا , ali su ustvari pobornici vesternizacije i otuđenja od islama. Svi sekularisti, modernisti i pobornici vesternizacije su iz ove grupe čije znanje o vjeri je takvo da nisu u stanju proučiti ajet iz Allahove knjige ili hadis Allahovog Poslanika na pravilan način. Oni se nazivaju učenicima Omera b. El-Hattaba koji je po njihovom mišljenju izbacio iz upotrebe neke kur'anske $\mathrm{i}$ hadiske tekstove, jer su u koliziji sa javnom, općom koristi, što je iftira i laž na koju je odgovorio šejh El-Karadavi u svojoj knjizi السياسة الشرعية. To su 
المعطلة nove mu'attile, odnosno. dobili su ime po sekti (المعطة الجدد) koja je lišavala Boga, s.v.t., Njegovih atributa u domenu akaida, a ovi Novi slično njima zapostavljaju parcijalne norme samo u domenu fikha.

3. Treća škola je المدرسة الوسطية ili škola srednjeg umjerenog puta koja ne zanemaruje parcijalne kur'anske tekstove i norme, niti vjerodostojni hadis i sunnet Allahovog Poslanika, a.s., ali i ne tumači ih odvojeno od općih ciljeva $\mathrm{i}$ intencija Šerijata, nego na njih gleda kroz njihovu prizmu i u njihovom duhu, tako da praktičnopravne propise vraća na njihove temelje; parcijalne, pojedinačne tekstove gleda u saglasju sa općim; promjenljive kategorije usaglašava sa stabilnim i nepromjenljivim; nejasne tekstove sa jasnim i razumljivim, držeći se pri tome vjerodostojnog teksta, kao i istinskog postignutog konsezusa ummeta. Ovaj metod u budućnosti može da predstavlja put muslimana (سبيل المؤمنين) od kojeg se ne bi smjelo odstupati, jer se razlikuje od (سبيل المجرمين ( puta onih koji nepravdu čine, a kojeg je Uzvišeni pokudio.

\section{Metodologija umjerene škole srednjeg puta المدرسة الوسطبة}

Škola srednjeg puta je primjena umjerenog programa za ummet srednjeg, umjerenog puta koji ne pretjeruje sa ekstremizmom, ali koji i ne zapostavlja i korektno se odnosi prema šerijatskim vrijednostima; to je škola pravog puta (الصراط المستقيم), koja ne prihvata ekstremizam, ali ni njegovu suprotnost, nego se drži umjerenosti i balansa, radeći po normi Uzvišenog: ,...da ne prelazite granice u mjerenju, /8/ i pravo mjerite i na tereziji ne zakidajte! /9/,5

Dakle, ovo je kur'anski balans i umjerenost, negdje između ekstremizma i zapostavljanja, što je princip škole koja pravi balans između parcijalnih tekstova $\mathrm{i}$ općih ciljeva i intencija Šerijata, odnosno razumijeva pojedinačne norme u svjetlu općih, bez ekstremnog razumijevanja bukvalnog, formalnog jezičkog značenja novih bukvalista, ali ne odbacujući, ne zapostavljajući i ne dokidajući tradicionalne tekstove, kao što čine pripadnici prozapadno orijentirane škole sekularizma ili škole koju nazvasmo škola Novih Mua'ttila.

\footnotetext{
${ }^{5}$ Kur'an:55:8-9.
} 
Umjerena srednja škola vjeruje da se šerijatski propisi moraju razumjeti u svjetlu efektivnih uzroka, da postoji mudrost i korist iza određenog propisa, da je Uzvišeni neovisan i nema potrebe kod svojih stvorenja kao što proklamuje:

$$
\text { (يأيها الناس أنتم الفقراء إلى الله، والله هوالغني الحميد) فاطر: } 10
$$

O ljudi, vi ste siromasi, vi trebate Allaha, a Allah je Neovisan $i$ hvale Dostojan. $/ 15^{\circ}$

Prema tome, Uzvišeni Allah, kada nešto naredi ili zabrani, kada nešto proglasi halalom ili haramom, to je iz razloga neke koristi za ljude, u to nema sumnje, spoznao to neko ili ne, jer je jedno Njegovo svojstvo (الحكمة) Mudrost, a od Njegovih lijepih imena je i (الحكيم) Mudri, koji neće praviti igrariju od propisa, nego će ih koncipirati mudro, shodno Svome svojstvu mudrosti, donoseći korist pravnim adresatima i društvu u cjelini. U Kur'anu se ta mudrost i svrsishodnost Božije Kreacije proklamuje na mnogo mjesta:

$$
\text { (ربنا ما خلقت هذا باطلا سبحاتك) آل عمران: } 191 \text { أ. } 1 \text { أ. }
$$

Ti ovo nisi uzalud stvorio! Uzvišen si Ti ...!" /191/7

$$
\text { (أفحسبتم أنما خلقناكم عبثا.) المؤمنون: } 11 \text { ( } 11 \text {. }
$$

'Zar ste mislili da smo vas uzalud stvorili ...?' /115/

$$
\text { (وما خلقتا السموات والأرض وما بينهما باطلا، ذلك ظن الأين كفروا) ص VV }
$$

"Mi nismo uzalud stvorili nebo i Zemlju i ono što je između njih; tako misle nevjernici...!"/27 $\rho$

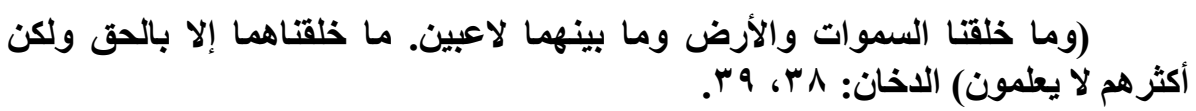

"Mi nismo stvorili nebesa $i$ Zemlju $i$ ono što je između njih da bismo se igrali." /38/ "Mi smo ih stvorili sa Istinom, ali većina njih ne zna." $/ 39 / 10$

\footnotetext{
${ }^{6}$ Kur'an:35:15.

${ }^{7}$ Kur'an:3:191.

${ }^{8}$ Kur'an:23:115.

${ }^{9}$ Kur'an:38:27.

${ }^{10}$ Kur'an:44:38-39.
} 
Dakle, Uzvišeni se ne igra Stvaranjem, Kreiranjem i propisivanjem, sve Njegovo djelovanje je djelo Mudrog, Svrhovitog... Imena Uzvišenog su i الرحيم الكريم Plemeniti, Milostivi i shodno onome što predstavljaju ta imena On kao Zakonodavac kada nešto propisuje čini to sa dozom milosti i plemenitosti jer je samom Sebi propisao Milost. Zbog svega toga nalazimo da Mudri Zakonodavac $\mathrm{u}$ tradicionalnim izvorima Šerijata (Kur'anu i sunnetu) obrazlaže mnogobrojne propise sa njihovim efektivnim uzrocima, mudrostima, koristima koje donose, posebno $u$ oblasti građanskog prava i međusobne komunikacije ljudi, zato je ulema gotovo na konsezusu da se šerijatski propisi obrazlažu efektivnim uzrocima i vezuju za mudrost i korist zbog kojih se donose. Šerijat se i uspostavlja zbog koristi koje donosi ljudima, bilo da se radi o stepenu nužde, potrebe ili luksuza i o tome vlada konsezus uleme koja ima predispozicije idžtihada. Eš-Šatibi, Ibnul-Kajjim, Ibn Tejmije i mnogi drugi smatraju da su temelji Šerijata i njegova zgrada oslonjeni na koristi koje priskrbljuju adresatima na ovom i budućem svijetu ili u svom vremenskom totalitetu, Šerijat je samo pravda, i samo milost, i samo mudrost i samo korist. Gazalija je shvatio da je cilj Šerijata naspram Allahovih stvorenja zaštititi im univerzalne vrijednosti: vjeru, život, pamet, porod, i imetak. El-Karafi je dodao i čast.

I to je ono u što vjeruje ova umjerena škola srednjeg puta koja ne zanemaruje ciljeve i intencije, niti tradicionalne tekstove; parcijalne pojedinačne tekstove razumije u svjetlu općih ciljeva i intencija; smatra da Uzvišeni Zakonodavac ne propisuje ništa što nije za dobro svojih stvorenja, da bi im priskrbio neku korist, ili otklonio neku štetu, i vjeruje da ne postoji ni jedan konačni, definitivni propis koji je u suprotnosti sa koristi koju treba priskrbiti za ljude, zbog toga što Onaj koji posla Šerijat i njegove propise i obaveza njima ljude, stvorio ih je, dao im nebrojene blagodati i On Uzvišeni definitivno zna šta je dobro za njih, čak i bolje od njih samih...

\section{Osnovne odlike i specifike umjerene škole islamske pravne misli سمات المدرسة الوسطية وخصائصها}

Umjerena škola srednjeg puta se odlikuje idejnim i etičkim svojstvima i specifičnostima i stoji negdje između dvije ranije spomenute škole. Šerijat je objavljen od strane Mudroga koji sve zna, 
tako da je isključeno da On objavi nešto što će Njegovim stvorenjima pričinjavati štetu u životu ili što će im otežavati život. Inače bi to bilo u koliziji sa Njegovim apsolutnim svojstvima znanja, mudrosti, milosti itd. i to je prosto nemoguće da se desi. Uzvišeni kaže:

$$
\text { (إن الله لا يخفى عليه شيء في الأرض ولا في السماء ) آل عمران: •. }
$$

"Allahu doista ništa nije skriveno, ni na Zemlji, ni na nebu!" $15 /^{11}$

\section{( ألا يعلم من خلق وهواللطيف الخبير) الملك: 14}

„A kako $i$ ne bi znao Onaj koji stvara, Onaj koji sve potanko zna, koji je o svemu potanko obaviješten. " $/ 14^{12}$

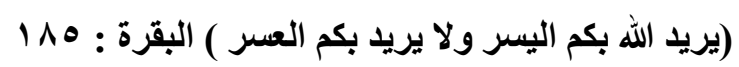

„,...Allah hoće da vam olakša, a ne da teškoće imate..." $/ 185^{13}$

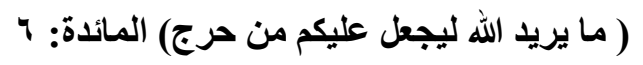

„,...Allah vam ne želi pričiniti poteškoće..."/6/ 14

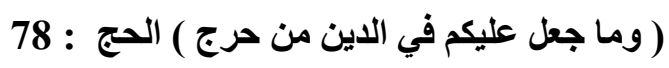

,....i u vjeri vam nije ništa teško propisao... /78/15

$$
\text { ( يريد الله أن يخفف عنكم وخلق الإنسان ضعيفا) النساء: ^^. }
$$

"Allah vam želi olakšati, a čovjek je stvoren slabim!"/28/16

I bilo bi u suprotnosti i koliziji sa Allahovim svojstvom milosti

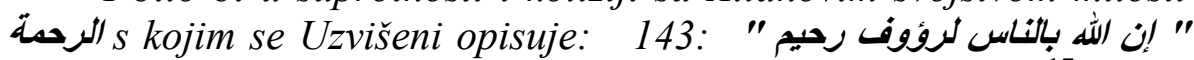
البقرة... a Allah je prema ljudima doista blag i milostiv."/143/17 kao $i$ sa prirodom Misije sa kojom je poslan Muhammed, a.s.,:

$$
\text { 107. (وما أرسلناتك إلا رحمة للعالمين ) الأنبياء }
$$

„.... a tebe smo samo kao milost svjetovima poslali. "107. ${ }^{18}$

\footnotetext{
${ }^{11}$ Kur'an:3:5.

12 Kur'an:67:14.

${ }^{13}$ Kur'an:2:185.

${ }^{14}$ Kur'an:5:6.

${ }^{15}$ Kur'an:22:78.

${ }^{16}$ Kur'an:4:28.

${ }^{17}$ Kur'an:2:143.

${ }^{18}$ Kur'an:21:107.
} 
Prema tome, ova umjerena škola srednjeg puta vjeruje da Šerijat sadrži sve ono što je milost za ljude, što im olakšava život, i što im pomaže u životu. Onaj ko vjeruje suprotno od toga, on gaji o Allahovom pravnom sistemu pogrešan, negativan sud, potvara Uzvišenog i Njegov sistem negativnim sudovima i u najmanju ruku nije na istini.

Da bi se pravilno razumjeli šerijatski izvori, mudžtehid mora imati znanstvene, intelektualne, moralne, fizičke i druge predispozicije, kako bi mogao na pravilan način pristupiti pozitivizaciji šerijatskih propisa.

Pravi, istiniti fikh s kojim Uzvišeni želi dobro njegovom يقهه في : " (Onaj kome Allah želi dobro podari mu znanje u vjeri), odnosi se na onog ko na tekstove kur'ansko-hadiskih normi pogleda sa stajališta intencija i ciljeva Šerijata.

Allahov Poslanik, a.s., je jednu grupu koja je donijela fetvu po doslovnom, bukvalnom značenju optužio da su počinili ubistvo. Naime, jedan ashab je bio ranjen i osvanuo džunup. Bez obzira na njegovo stanje i ranu, njemu su izdali fetvu da se mora kupati. On je poslušao, okupao se, vjerovatno i nahladio, tako da se rana zakomplicirala $\mathrm{i}$ on je umro. Vijest o ovom slučaju doprla je do Allahovog Poslanika, a.s., koji je tim povodom rekao: ,Ubili su ga, Allah ih ubio! Zašto nisu pitali kad ne znaju!? Lijek nesposobnog $i$ neznalice je pitati. Njemu je bilo dovoljno da previje ranu i da uzme tejemum.

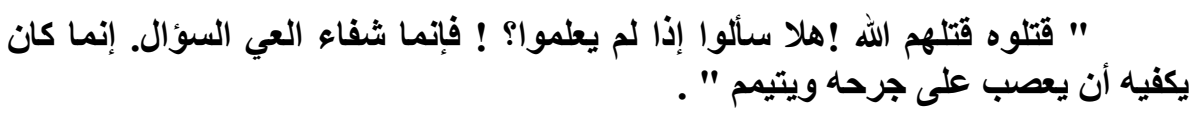

Dakle, fetvu koja nije bila utemeljena na znanju, proglasio je ubistvom: "Ubǐ̌e ga, Allah ih ubio...!"

Navest ćemo nekoliko primjera iz različitih oblasti da se pokaže obaveza vezivanja između parcijalnog dokaza i općeg cilja i intencije hadisa da bi se dospjelo do ispravnog šerijatskog propisa. 


\section{Neka praktična rješenja umjerene škole islamske pravne misli:}

\section{a) Postojanje dva nisaba za zekjat novčane vrijednosti وجود نصابين للنقود في الزكاة}

Allahov Poslanik, a.s., je odredio dva nisaba za zekjat novčane vijednosti i to nisab srebra visine 200 dirhema, novca koji je dolazio iz Perzije, ili 595 gr. zlata i 20 dinara, novca koji je dolazio iz Vizantije, ili 85 gr. Arapi nisu imali vlastitog novca, pa su se i ekonomske transakcije odvijale ovim platežnim sredstvima. Odnos te dvije novčanice bio je 10:1 u korist dinara. Kod analize i definiranja zekjata očito je da zekjat nije samo čisti ,duhovni“ ibadet, kao što su post ili namaz, nego sadrži imovinsko pravo i dimenziju, tako da se kao pitanje tretira ne samo u obredoslovlju, nego i u islamskoj ekonomiji i islamskom društveno-političkom sistemu. Rješenje ovog pitanja zahtijeva različite pristupe; analogiju, uzimanje efektivnog uzroka propisu i sl., tako da je potrebno vidjeti običaj ili korist zbog koje je propisan i da li se to promijenilo protokom vremena. Poslanik, a.s., je odredio nisab kao najnižu granicu bogatstva na koji se mora dati zekjat, a odredio je to na temelju običajnog odnosa prema tadašnjem upotrebnom novcu dvije valute. Zbog toga, ako se danas promijenio odnos ove dvije valute, tako da je jedna opala u odnosu na drugu i to $\mathrm{u}$ značajnom omjeru, nije dozvoljeno pozivati se na dva nisaba $i$ primjenjivati onaj koji je pogodniji, posebno ako se radi o deseterostrukim omjerima. Izlaz iz ove situacije je da se odredi jedan nisab u odnosu prema novčanoj vrijednosti koji će biti najniža kategorija bogatog koji treba dati zekjat i tako su savremeni poznati učenjaci, kao što su Muhammed Ebu-Zehre, Abdul-Vehhab Hallaf, Abdur-Rahman Hasen i dr., donijeli fetvu o jednom nisabu preračunatom $\mathrm{u}$ valuti zlata. To nije u koliziji sa tekstom norme hadisa, koji je predvidio dva nisaba iz dvije različite valute, pošto se ovdje radilo o tada vladajućem običaju koji kada se promijeni protokom vremena nema zapreke da se promijeni i propis vezan za njega.

\section{b) Putovanje žene sa mahremom}

\section{سفر المرأة مع محرم}

U Buharijevoj i Muslimovoj zbirci hadisa zabilježena je predaja Ibni A'bbasa u kojoj se kaže: لا تسافر امرأة إلا مع ذي محرم (Neka žena ne 
putuje osim u društvu sa mahremom). Efektivni uzrok ovoj normi je bila briga za ženu i strah da putuje bez zaštitnika, muža ili nekog drugog mahrema, u vremenu kada je putovanje bilo opasno i naporno u svakom smislu, tako da i ako bi se žena spasila od opasnosti puta, ne bi se mogla spasiti od krnjenja ugleda zbog prirode puta i sredstava kojima se putovalo.

Ako se promijeni situacija, kao što je slučaj danas, da se putuje savremenim sredstvima u kojima nema takve bojazni za ženu, onda ne bi bilo šerijatske zapreke, niti bi to bilo u suprotnosti sa spomenutom normom da žena putuje uz prisustvo stotina drugih putnika, koji se nalaze u avionu, vozu, autobusu i sl. Tako je ulema dozvolila da žena putuje na hadž bez mahrema i muža u društvu sa drugim ženama koje su poštene i povjerljive, i u organizaciji povjerljivih, kao što je bio slučaj i sa ženama Allahovog Poslanika, a.s., koje su u vrijeme halife Omera putovale u društvu Osmana b. Affana i Abdur-Rahmana b. A'vfa. Neki su dozvolili da žena putuje na hadž i u'mru, ako je sa njom makar samo jedna povjerljiva žena, dok su neki dozvolili putovanje samostalno, u slučaju da je put siguran i da nema opasnosti. Šafijska ulema je to proširila i na druga putovanja osim hadža i u'mre.

\section{c) Dolazak ženi sa puta noću, iznenada}

\section{طروق الرجل المسافر أهله ليلاً}

Protumačeno je kao zabrana u hadisu Allahovog Poslanika, a.s., da čovjek, ako se duže vrijeme zadržao na putu, dođe ženi po noći i zalupa joj na vrata. To nikada nije bila njegova, a.s., praksa, nego bi nastojao sa puta doći pred noć ili ujutro. Efektivni uzrok ovoj zabrani je činjenica da bi se na takav način čovjek pokazao kao onaj koji sumnja u svoju ženu i nastoji iznenadnim, nenajavljenim dolaskom otkriti nešto što ženi ne bi bilo pravo. To bi bila nepravedna sumnja koju islam zabranjuje, posebno u bračnim odnosima sa najvišim stupnjem povjerenja i veze koju mogu imati dva ljudska bića. Najavljeni dolazak ima prednost kako bi se žena mogla pripremiti za muža, urediti, počešljati, uljepšati i slično; to je sačuvano u predajama kao objašnjenje ove zabrane.

U današnje vrijeme potpuno je izmijenjena situacija, tako da i ova zabrana nema više efekta, zbog toga što se može reći da putnik ima mogućnost da se javi ženi telefonom, internetom, faksom i sl., sa 
bilo kojeg mjesta i u bilo koje vrijeme i da je ne iznenadi svojim eventualnim dolaskom. Ujedno, putnik u savremeno doba, za razliku od prošlog vremena kada je putovao uglavnom svojim prevoznim sredstvom, devom, konjem, i sl., vezan je i ograničen voznim redom prevoznih sredstava, gdje ne može da bira vrijeme i termin dolaska kući.

\section{d) Tumačenje hadisa o boravku među mušricima: " بين أظهر المشركين لا تتراءى نارهما " أنا برئ من كل مسلم يقيم}

Odričem se svakog muslimana koji boravi među nevjernicima, njihove vatre se ne smiju međusobno vidjeti.

Neki su razumjeli iz ovog hadisa da je zabranjeno boraviti u neislamskim zemljama tako da su u nekim islamskim zemljama izdane fetve zabrane boravka i pričinjena je ogromna poteškoća muslimanima u dijaspori, Evropi, Americi i drugim zapadnim zemljama, uz njihovu nužnu potrebu za boravkom $u$ takvim neislamskim zemljama zbog studiranja, liječenja, zaposlenja, trgovine, bjekstva od nepravednih režima, misionarenja i sl. , a posebno u ovom savremenom dobu kada je čitav svijet zbog tehničko-tehnološkog napretka postao veliko globalno selo.

Pravo značenje hadisa je da Allahov Poslanik, a.s., ne odgovara ako takav bude ubijen, jer je sam sebe doveo u opasnost boravkom među onima koji su neprijatelji islama i islamske države.

Međutim, ako se promijeni situacija zbog koje je izgovorena neka norma i prestane njen efektivni uzrok u vidu koristi koja se može priskrbiti ili štete koja se može otkloniti i spriječiti, razumljivo je da prestaje i propis koji se ranije ustalio sa tom normom, tako da se propis vezuje za efektivni uzrok koji ako postoji, postoji i propis, i obratno ako prestane prestaje i propis.

\section{e) Tumačenja hadisa o predvodniku iz plemena Kurejš :

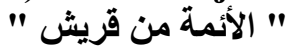

Hadis u značenju: „,Predvodnici-vladari su iz plemena Kurejš “ i drugi u ovom smislu neka ulema ne prihvata uopće, drugi su ga pokušali osporiti sa aspekta predaje, iako postoje i vjerodostojne verzije. Treći su ga prihvatili, ne kao doktrinarnu obavezu, nego kao 
normu koju treba razumjeti u svjetlu ciljeva i intencija, odnosno sa aspekta efektivnog uzroka, koji, ako postoji, onda postoji i propis i obratno. Tako je i Ibn-Haldun razumio da je Allahov Poslanik vidio kod plemena Kurejš postojanje plemenskog asabijjeta i snage sa kojima se vlada i upravlja autoritetom kojeg drugi prihvataju. Zbog toga, smatra da ako se potvrdi i kod nekog drugog, osim Kurejševića, postojanje asabijjeta i snage koja neutrališe međusobe trzavice i svađe u vlasti, onda je to taj efektivni uzrok ili uvjet za predvodnika/vladara i takav može da bude izabran bez obzira na plemensku pripadnost spomenutu $\mathrm{u}$ hadisu, kako bi se izbjegle svađe i netrpeljivost $\mathrm{i}$ ujedinili muslimani...

\section{Razlikovanje konstantnih ciljeva i intencija od promjenljivih sredstava u islamskoj pravnoj misli \\ التمييز بين المقاصد الثابتة والوسائل المتغيرة}

Udubljivanje u šerijatske propise, njegove naređujuće i zabranjujuće dispozicije rezultira činjenicom da se mogu odrediti traženi postulati dok se ne određuju sredstva kojima se to postiže, pošto su sredstva podložna promjeni i različitom shvatanju, u zavisnosti od vremena i mjesta, običaja, društvenog, političkog i ekonomskog miljea, tako da Zakonodavac to ne ograničava ostavljajući adresatima mogućnost izbora određenog sredstva da njime stigne do cilja koji mu je Šerijat propisao.

Primjer za to je propisivanje postulata dogovora (مبدأ الشورى) specijalno u pitanjima politike i vlasti, koji su došli u tradicionalnim tekstovima kao što je ajet iz mekkanskog perioda:

$$
\text { (وأمرهم شورى بينهم ) الثوري: ^ץ" }
$$

"... i o poslovima svojim se dogovaraju, ...", /38/19 , da bi poslije u medinskom periodu Objave bila izrečena naredba i proklamovan postulat šure:

$$
\text { ( وشاورهم في الأمر ) آل عمران: } 109 .
$$

“...i dogovaraj se s njima! ..." /159/20

\footnotetext{
${ }^{19}$ Kur'an:42:38.

${ }^{20}$ Kur'an:3:159.
} 
Postulat šure je, dakle, utemeljen i proklamovan normom najviše pravne snage, ali sredstvo za postizanje nije određeno; nije određeno kako će se ispoštovati princip šure i dogovora, ko su savjetnici i članovi šure, kako se biraju članovi tijela i vijeća koje će se baviti tim pitanjima, kako će se birati i postavljati halifa i sl.; sve ovo je ostavljeno da se uredi na neki drugi način i Adresant nije odredio i propisao pravna sredstva za to ostavljajući muslimanima jednog vremena i prostora da sami svojim pravničkim rasuđivanjem dođu do njih. Tako su se i načini izbora prvih 4 pravednih halifa razlikovali i nisu imali istu formu. $U$ našem vremenu može se odabrati demokratski put izbora većine, kako je to uređeno u savremenim demokratskim društvima.

Slično tome je i sa principom naređivanja dobra i zabrane zla koje se može sprovesti sa jednim od tri sredstva: rukom, jezikom ili osudom u srcu.

فريضة Norma je došla općenita i stepena je kolektivne obaveze كفائية na muslimane, dok samo u pojedinim slučajevima prelazi u ličnu, pojedinačnu obavezu. Ali, kako praktično uređujemo ovu kolektivnu obavezu, ko je obavezan, koliki je stepen i udio izvršne vlasti u njenoj realizaciji itd., sve ovo je u domenu i prakticirano u sistemu nadgledanja i inspekcije (نظام الحِنْبة) kojeg su otkrili i inovirali muslimani, postavljajući mu nužne propise, odredbe i uvjete potrebne za njegovo normalno funkcioniranje.

U Šerijatu nalazimo dosta ovakvih postulata (المبادئ) ili ciljeva i intencija (المقاصد) čije praktično sprovođenje i sredstva sa kojima će se to uraditi Mudri Zakonodavac je izostavio, ne iz razloga što je zaboravio ili mu je to promaklo, nego iz mudrosti i želje da olakša ljudima što ulazi u domen opraštanja (منطقة العفو) i svjesnog olakšavanja iz velike milosti, a da bi ljudi sami sebi putem kijasa analogije, istihsana - pravničkog preferiranja ili po principu općih, javnih koristi pravno uredili te propise.

\section{Određivanje pravnog sredstva kompatibilnog vremenu i prostoru تعيين وسيلة مناسبة للزمان والمكان}

Mudri Zakonodavac je odredio sredstva kompatibilna vremenu i prostoru da bi ostvario ciljeve Šerijata. Nije želio da ta sredstva budu 
svugdje i zauvijek, za svako vrijeme i svaki prostor, nego je time želio da uzme u obzir situaciju adresata i njegovo vrijeme.

\section{Razlikovanje ciljeva i intencija od pravnih sredstava التمييز بين المقاصد والوسائل}

Određivanje spomenutih sredstava bilo je ponekad pogrešno razumijevanje Šerijata, gdje su neki zamijenili konstantne ciljeve i intencije sa pravnim sredstvima koji su primjereni mjestu i vremenu i putem kojih se ponekad dolazi do očekivanog cilja koji traži Zakonodavac, tako da su vidljivi kako se upinju iz petnih žila da označe ta sredstva, kao da su ona najviši konstantni i svevremenski cilj, iako je jasno onom ko se udubi u razumijevanje tekstova normi i tajni koje oni skrivaju, da je to isključivo trajni, konstantni cilj i intencija, a ne sredstvo koje se mijenja promjenom mjesta, vremena, običaja i drugih promjenljivosti koje privremeno djeluju na propis...

\section{Tumačenje izraza „Konj“6 kao ratno sredstvo وسيلة رباط الخيل}

Čak kada i Kur'an, koji je šerijatski izvor sa najvišom pravnom snagom, direktno spominje u svojoj normi neko određeno sredstvo, specifično za određeno mjesto i određeno vrijeme, to ne znači da je samo to cilj i da ne razmišljamo o drugim savremenim sredstvima koji ga mogu zamijeniti u dostizanju očekivanog cilja Zakonodavca. Kur'an spominje sredstvo ratovanja koje je bilo značajno u vrijeme objave ove norme:

$$
\text { وآخرين من دونهم ) الأنفال: • 7. أهنتم من قوة ومن رباط الخيل ترهبون به عدوالله وعدوكم }
$$

"I protiv njih pripremite koliko god možete snage i konja za boj, da biste time zaplašili Allahove i vaše neprijatelje, i druge osim njih ..." $/ 60 /{ }^{21}$

Niko nije razumio da se u ratnoj pripremi protiv neprijatelja ima koristiti samo „konjski“ potencijal koji je Kur'an eksplicitno spomenuo u ovom ajetu. Svi obdareni pameću i razumom, koji znaju arapski jezik na kojem je objavljen Kur'an i iole se razumiju u pravnu

\footnotetext{
${ }^{21}$ Kur'an:8:60.
} 
logiku, shvataju da su savremeni ,ratno-konjski“" potencijali i sredstva predstavljeni u svim vrstama modernog naoružanja, a da taj arsenal nije ograničen na eksplicite spomenuti izraz u ovoj kur'anskoj normi. Isto tako, mnogobrojne hadiske predaje koje govore o izuzetnoj vrijednosti, davanja, uzgoja i upotrebe konja u džihadu, mogu se shvatiti samo vremenski i prostorno i te vrijednosti i sevape prenijeti na sredstva koja u današnjem vremenu imaju daleko veću vrijednost od konja zamjenjujući ga kao ratno sredstvo, kao što su: puške, tenkovi, rakete, borbeni avioni i helikopteri, eksploziv, bombe itd.

Allahov Poslanik je rekao:

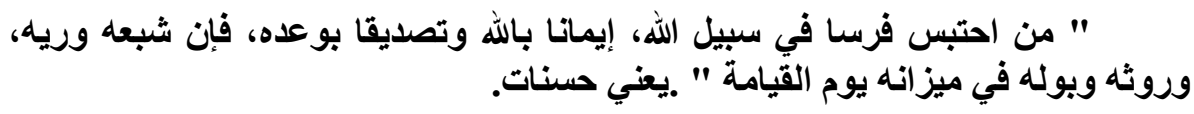

Onaj ko odredi konja za Allahovog puta, s vjerom u Allaha $i$ uvjernjem u Njegovo obećanje; njegovo hranjenje i pojenje, njegova fuškija i urin obračunaće se na Sudnjem danu.

Istu logiku treba primijeniti i na hadiske norme koje govore o vrijednosti bacanja strijela na Allahovom putu kao što su hadisi $u$ smislu:

\section{" من رمى بسهم في سبيل الله فله كذا وكذا " .}

Ko se baci strelom na Božijem putu imaće nagradu takvu $i$ takvu...

Dakle, vrijednost bacanja strijele nije glavni cilj ove norme, nego je to samo sredstvo, a vrijednost nagrade se prenosi i na svako drugo savremeno sredstvo čiji efekat „bacanja“ je daleko veći nego efekat strijele, kao što su puška, top, raketa itd.

Isti je slučaj i sa spomenutom odjećom u kur'anskoj normi sa kojom se želi postići propis o pokrivanju za ženu muslimanku. Uzvišeni kaže:

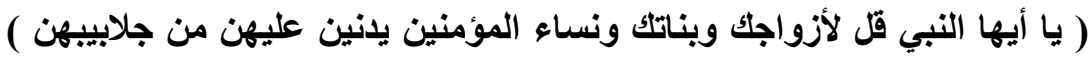

"O Vjerovjesniče, reci ženama svojim, i kćerima svojim, $i$ ženama vjernika neka spuste haljine svoje niza se... $/ 59 /^{22}$

${ }^{22}$ Kur'an:33:59. 
Ova norma ne znači da je „džilbab“ jedini način oblačenja žene muslimanke, pošto je oblačenje dio običaja određenog mjesta i mogu se obući dimije, mantil, kaput itd., u zavisnosti od običaja i da se zadovolji šerijatski propis pokrivanja onih djelova tijela koji je obaveza da se pokriju, da odjeća ne bude providna i tijesna...

Također, misvak je sredstvo za čišćenje zuba i cilj njegove upotrebe je čišćenje kao što se spominje u hadisu:

$$
\text { " السواك مطهرة للفم مرضاة للرب. " }
$$

Misvak čisti usta i zadovoljava Gospodara.

Naravno da nema nikakve šerijatske zapreke da u drugim društvima osim arapskog, gdje je misvak nepoznat, umjesto misvaka, četkica posluži za čišćenje zuba milionima ljudi, što su potvrdili i neki šerijatski pravnici.

\section{Viđenje hilala za utvrđivanje lunarnog mjeseca روية الهلال لإثبات الثهر}

Zabilježeno je u vjerodostojnom, poznatom hadisu:

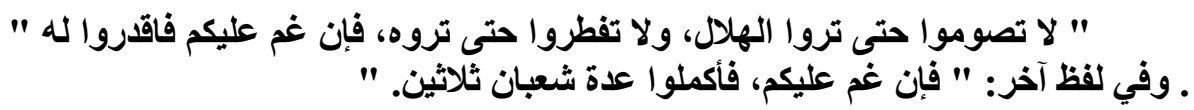

„Nemojte postiti dok ne vidite mlađak, niti prekinuti post dok ga ne vidite, a ako bude oblačno onda odredite... " u drugoj verziji je zapisano: „A ako bude oblačno onda upotpunite mjesec ša'ban trideset dana. "

Moguće je reći da hadis ukazuje na cilj i određuje sredstvo. Cilj je jasan, a to je da se posti cijeli ramazan i da se ne promaši ni jedan dan na početku ili izgubi na kraju, ili da se ne posti u drugom mjesecu osim ramazana, kao što je ša'ban ili ševval, a to se ostvaruje utvrđivanjem početka i kraja mjeseca sredstvom koje je bilo moguće za većinu ljudi u vrijeme kada je ova norma izdata i nije im predstavljalo poteškoću u njihovoj vjeri. Viđenje mlađaka golim okom bilo je moguće sredstvo, lahko sprovodivo za običnog čovjeka u tom vremenu, zbog čega je u hadisu upravo to zabilježeno kao sredstvo određivanja, a ne nešto drugo, kao recimo astrološki proračun koji je bio nepoznat običnim, nepismenim ljudima koji nisu pisali i nisu znali 
računati, pa bi im takvo sredstvo predstavljalo nepremostivu prepreku, a Uzvišeni i Mudri Zakonodavac želi da im olakša, a ne da oteža.

Zato, ako se nađe neko drugo sredstvo, koje će biti efikasnije u ostvarenju šerijatskog cilja navedenog hadisa, i biti dalje od mogućnosti pogreške oko određivanja mjeseca, a u isto vrijeme biti lahko i moguće za primjenu kod običnog čovjeka, nakon što su se pojavili učenjaci koji razumiju astrologiju, fiziku, hemiju, nakon što je čovjek kročio na mjesec itd. U tom slučaju, zašto bi insistirali isključivo na sredstvu viđenja, koje nije cilj sam po sebi, a da izostavimo i zanemarimo cilj koji proklamuje hadis. Ujedno, hadisom je određeno da se može dati povjerenje i prihvatiti dokaz svjedočenja od samo jednog svjedoka, koji golim okom vidi mlađak, pošto je to bilo jedino moguće sredstvo tadašnjeg vremena. Pa kad je to tako, kako onda da se ne prihvati i proračun koji je na stepenu kategoričkog znanja $u$ odnosu na vijest od jedne osobe, na koji se može dati konsezus islamskog ummeta, pa da se dokinu razlike u određivanju početka ramazana ili za Bajram kada u pojedinim islamskim zemljama razlika bude $\mathrm{i}$ do tri dana, što je neprihvatljivo i sa stajališta vjere, logike i zdrave pameti, jer je neko u ovom slučaju u pravu, a ostali nisu. Uzimanje astrološkog proračuna, kao sredstva u određivanju mjeseca, trebalo bi se uzeti obavezno kao preči kijas-analogiju قياس) وسيلة أدنى iz razloga što je sunnet propisao najniže sredstvo الأولى) kojim se viđenje može postići, a to je viđenje golim okom jednog svjedoka, uz stanovitu nepreciznost i mogućnost razlaza koji je bio evidentan kroz historiju, pa i danas, a zbog kojeg ne bi trebalo ostaviti više sredstvo وسيلة أعلى koje je potpunije i daje optimalnije izvršenje zadanog cilja Zakonodavca nudeći izlazak islamskog ummeta iz sfere žestokog razlaza kod određivanja početka i kraja ramazana i Bajrama, u domen očekivanog jedinstva islamskog ummeta, budeći nadu da se ono može postići i u najspecifičnijim simbolima vjere i ibadeta.

Veliki islamski učenjak Ahmed Muhammed Šakir je mišljenja da je došlo vrijeme za određivanje početka mjeseca proračunom, iz jednostavnog razloga što propis viđenja i svjedočenja spomenut $u$ hadisu ima svoj efektivni uzrok, a on je prestao u ovom vremenu, pa treba da prestane i njegov propis, pošto je prihvaćeni princip da se propis vezuje za svoj efektivni uzrok postojanjem ili nepostojanjem. 
Buharija je zabilježio hadis Ibni Omera kojeg bilježi i Malik u svom Muvettau:

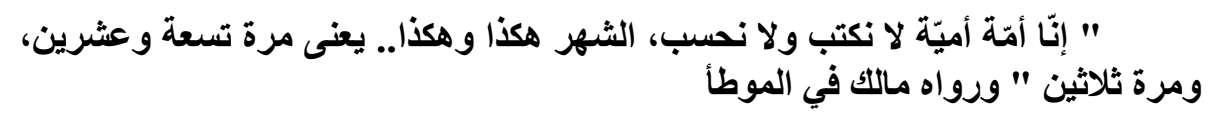

Mi smo nepismeni ummet koji ne piše $i$ ne računa, mjesec je $i$ ovako i onako... tj., jednom je 29 ali drugi put je 30 (dana).

U ovom slučaju efektivni uzrok u vidu kvalifikacije o „nepismenom ummetu (الأمة أمية) koji ne piše i ne računa“, što je važio za vrijeme Objave, prestao je u današnje vrijeme gdje postoje učeni pojedinci koji se razumiju u astrološki proračun. Dakle, promijenio se opis islamskog ummeta koji sada ,piše i računa“, tako da je moguće i logično da se promijeni i propis gledanja golim okom u propis proračuna koji je u to prvo vrijeme bio nedostižan, jer da je tada propisan predstavljalo bi poteškoću i otežavanje nepismenom ummetu koji to ne bi mogao tada ispoštovati....

Ovo je Ahmed Muhammed Šakir objavio još u Zil - hidždži 1357. odnosno u januaru 1939. godine.

Interesantno je da su neki učenjaci u svom zahirskom, formalističkom, bukvalnom, doslovnom pristupu pokušali osporiti proračun hadisom koji opisuje islamski ummet kao onaj koji „ne piše i ne računa" što bi po istom principu onda zabranilo i pismenost, a to se ipak nije usudio reći niko od pripadnika islamskog ummeta.

Također, Buharija je zabilježio u poglavlju o postu sa zlatnim lancem prenosilaca poznat od Malika preko Nafi'a do Ibn Omera da je Allahov Poslanik spomenuo ramazan rekavši:

\section{" لا تصوموا حتى تروا الهلال، ولا تفطروا حتى تروه، فإن غم عليكم فاقدروا له "}

Ne zapašćajte dok ne vidite mlađak, i ne mrsite dok ga ne vidite, a ako bude kod vas oblačno onda odredite...

Ovo naređeno vremensko određivanje i ocjena može sasvim legitimno da se odnosi i na astrološki, matematički proračun za one rijetke koji su to mogli i znali, a što je u našem vremenu postalo od aksioma znanosti i dostupno posredno ili neposredno do svakog pojedinca razvojem astrologije i telekomunikacijskih znanosti. 
Neki savremeni učenjaci (Jusuf El-Karadavi) su pozivali na uzimanje po proračunu, u slučaju negiranja mogućnosti viđenja, ostavljajući validnim svjedočenje viđenja i potvrđivanja u slučaju mogućeg viđenja. Šta bi to značilo? To bi značilo da ako se proračunom utvrdi od strane poznavalaca ove znanosti kao nemogućnost viđenja mlađaka, onda je to definitivni, konačni قطعي dokaz koji treba da se ispoštuje i da se uopće ne osvrće na svjedočenja koja bi eventualno mogla doći u tom vremenu, iz razloga što bi svjedočenje od neke osobe bilo na stepenu pojedinačne vijesti, stepenu nekategoričkog ili pojedinačnog ظني dokaza, što se u koliziji sa kategoričkim dokazom, tj., u ovom slučaju znanstvenim proračunom ne uzima se u obzir.

Isto ovo je zastupao i šafijski učenjak Tekijjud-Din Es-Subki (umro 756) za kojeg se drži da je dostigao stepen mudžtehida. On spominje da je obaveza sudije koji proglašava početak ramazana, u slučaju ako je situacija takva da se mlađak ne može vidjeti golim okom zbog prirodne oblačnosti, kiše i sl., da odbije svjedočenje u takvoj situaciji i pribjegne proračunu, pošto svjedoci nisu mogli vidjeti u takvoj situaciji. Tako se preferira proračun kao definitivan, jer se svjedočenje i viđenje računaju kao nedefinitivni i slabije pravne snage, a da bi se mogli podrediti ili suprostaviti definitivnom. I tako je kod svih svjedočenja, koja ako su u osnovi nemoguća, onda ih Šerijat odbija i ne prihvata. Ipak, u slučaju eventualnog svjedočenja koje bi neko prijavio u smislu da je vidio hilal u tom vremenu, ono se objašnjava greškom, pričinjavanjem ili da je izrečena laž.

\section{Opasnost preinačavanja ciljeva i intencija u sredstva i obratno خطر تحويل المقاصد إلى وسائل أوالعكس}

Neki ateisti koji ne drže do ibadeta i pokornosti Allahu, dž.š., površni ili licemjerni ibadet koji vide kod nekih pripadnika, a koji ne dopire do srca niti oplemenjuje osobu, ne brani im da čine grijehe, žele to iskoristiti i govore u ovom smislu: „Cilj vjere, njene ideologije i njenog obredoslovlja je da očisti osobu, da je odgoji, da je moralno uzdigne i sl.; pa ako se do tog cilja dođe i nekim drugim sredstvom, kao što je osobno uzdizanje, konvencionalnim moralom i etikom, onda nismo u potrebi za vjerskim obredoslovljem, niti za simbolima vjere, niti za namazom i hadžom jer su to sredstva, a ne ciljevi, a 
dospjeli smo do cilja kojeg želi Bog od nas, pa zašto da se držimo samo određenog sredstva?!”

Ovo je, naravno, vid kufura i izbjegavanje obaveza vjere, obaveza prema Uzvišenom Gospodaru, te promašaj biti i svrhe čovječijeg bivstvovanja na ovom svijetu, a odgoj i moralno uzdizanje ljudske osobe je samo rezultat istinskog ibadeta a ne efektivni uzrok njemu.

$$
\text { (وما خلقت الجن والإنس إلا ليعبدون ) الذاريات: } 7 \text { هـ }
$$

Džine i ljude sam stvorio samo zato da Me obožavaju 156 /3. $^{23}$.

\section{Osnovni, fundamentalni i sekundarni cilj u ibadetu ومقاصد تابعة للعبادة مقصد أصلي}

Po imamu Šatibiji, ibadet sadrži dva cilja: osnovni i sekundarni. Osnovni je predstavljen u tome da se okrene Jedinom Koji zaslužuje obožavanje služeći $\mathrm{Mu}$, pokoran u svakom smislu i situaciji što rezultira ciljem postizanja eshatološke vrijednosti ili u ovosvjetskom smislu da bude od Allahovih dobrih robova i sl., dok je sekundarni cilj predstavljen u duhovnom osobnom uzdizanju i privređivanju osobnih vrijednosti.

Ukratko, svaka ideja koja poziva na zaborav osnovnog cilja u ibadetu činjenjem i prakticiranjem sekundarnog na koje nastoji okrenuti svjetlo temeljnog ibadeta ili to proglasiti prvim ciljem vjere ili ciljem zbog kojeg je stvoren čovjek, mikrokosmos i makrokosmos, to je sotonistička ideja apokalipse, katastrofe i uništenja i ne prihvata se...

\section{Kompatibilnost između nepromjenljivog i promjenljivog الملائمة بين الثوابت والمتفيرات}

Od osnovnih odlika umjerene škole srednjeg puta je to da usklađuje nepromjenljive šerijatske aksiome i promjenljiva sredstva koja su kompatibilna mjestu, vremenu i situaciji. Što se tiče nepromjenljivih aksioma, oni opstaju svevremeno u svim situacijama $i$ ljudski upliv idžtihadom nije dozvoljen u tom domenu, niti ih dotiče

${ }^{23}$ Kur'an:51:56. 
napredak ili pokušaj reformizma. Ovi nepromjenljivi aksiomi predstavljeni su u slijedećem:

1. osnovna doktrina العقائد الأساسية kao što je npr.: vjerovanje u ruknove imana, vjerovanje u Allaha, Njegove meleke, poslanike, knjige, Sudnji dan, ono što je spomenuto u Kur'anu, zatim vjerovanje u Božije određenje što je potvrđeno sunnetom;

2. praktični ruknovi islama أركان الإسلام العملية kao što su dva šehadeta, namaz, zekjat, post ramazana i hadž za onoga ko je u mogućnosti;

3. univerzalne etičke vrijednosti أمهات الفضائل الأخلاقية koje je proklamovao Kur'an kao etiku i moral vjernika i što je proklamovao sunnet od dijelova imana kao što su: pravda, dobročinstvo, pomaganje rodbine, istinoljubivost, povjerljivost, milost, strpljivost i zahvala, stid itd.;

4. jasno i kategorički zabranjeno أمهات المحرمات القطعية الظاهرة kao što su: ubistvo, zinaluk, seksualne perverzije, konzumiranje alkohola, krađa, otimačina, sihir, kamata, prisvajanje imetka siročeta, potvaranje žena muslimanki, bježanje sa bojnog polja, neposlušnost roditeljima, prekidanje rodbinskih veza, ogovaranje i prenošenje, laž, nasrtaj na tuđa prava;

5. unutrašnje zabrane المحرمات الباطنة kao što su: oholost, zavist, mržnja, licemjerstvo i samodopadljivost, nekontrolisana ljubav prema dunjaluku, slijeđenje ispraznosti, tvrdičluk;

6. krovni definitivni propisi jela, pića, oblačenja i ukrašavanja, kupovine i prodaje, imovinskih transakcija, braka, razvoda, oporuka, nasljeđivanja, fiksiranih kazni kao što su kisas i hudud propisane Kur'anom.

Sve ovo su trajne vrijednosti i aksiomi koji se ne smiju narušavati ni u kojoj situaciji, zbog toga što nisu podložni ljudskom uplivu i idžtihadu i zbog toga što su definitivni vjerodostojnošću dopiranja do nas, kao što su i kategorički sa aspekta nedvosmislenog jasnog ukazivanja na upravo to značenje i propis koji više ne podliježe sudu savremenosti ili revidiranja.

Jasno je da je krug ovih trajnih definitivnih vrijednosti veoma ograničen, ali $u$ isto vrijeme $i$ veoma važan, i ukazuje na elemente 
identiteta islamskog ummeta, gradi njegovu osobenost i odlikovanost, čuvajući ga od utapanja i nestajanja, čuvajući njegovo jedinstvo i ne dozvoljavajući njegovo rasipanje nakon što ga je Uzvišeni proglasio ummetom srednjeg puta.

Svi drugi pojedinačni i praktičnopravni propisi الفرعية والجزئية الأحكام su propisi koji su podložni promjeni i izmjeni, jer su potvrđeni nedefinitivnim dokazom u smislu vjerodostojnosti ili u smislu upućivanja baš na taj propis i takav je slučaj sa većinom šerijatskopravnih propisa podložnih revidiranju i savremenom tumačenju.

Sekularisti pokušavaju pobrisati granicu između ove dvije vrste propisa kako bi trajne aksiološke vrijednosti doživjele promjenu i na takav način se zadao konačni udarac islamskom šerijatskom zakonodavstvu. Umjerena škola srednjeg puta stoji u odbrani šerijatskog zakonodavstva.

\section{Sumnje sekularista}

Sekularisti su izrazili sumnju oko definitivnog šerijatskog teksta u smislu vjerodostojnosti, a koji je konačan i u smislu upućuvanja na neki propis, da li se kao takav sprovodi i prakticira, ako u tom prakticiranju dolazi do štete u koristima muslimana. Odnosno, željeli su moratorij na fiksirane kazne مسائل الحدود i zabranu kamate... dakle u pitanju su tekstovi i kur'ansko-sunnetske norme kao što su:

$$
\begin{aligned}
& \text { (وأحل الله البيع وحرم الربا) البقرة: rvo }
\end{aligned}
$$

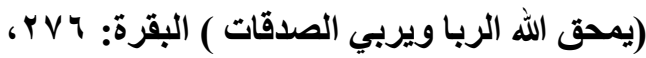

A Allah je dozvolio trgovinu, a zabranio kamatu..."/275

"Allah uništava kamatu, a umnožava milostinje !" /276//24

(والسارق والسارقة فاقطعوا أيديهما جزاء بما كسبا نكالا من الله ) المائدة: ^^ب،

"Kradljivcu i kradljivici odsijecite ruke njihove, neka im to bude kazna za ono što su učinili i opomena od Allaha!" $/ 382^{25}$

${ }^{24}$ Kur'an:2:275-276.

${ }^{25}$ Kur'an:5:24. 


\section{(إنما جزاء الذين يحاريون الله ورسوله ويسعون في الأرض فسادا أن يقتلوا}

أويصلبوا.) المائدة: سماع الاين

"Kazna za one koji protiv Allaha i Poslanika Njegova vojuju $i$ koji nered na Zemlji čine jeste: da budu ubijeni, ili razapeti... "/33/

\section{وقوله صلى الله عليه وسلم: " من بدل دينه فاقتلوه"}

Riječi Allahovog Poslanika, a.s.: Onaj ko promijeni vjeru ubijte ga.

Dakle, oni koji dovode u pitanje primjenu ovih tekstova zanijekali su kategoričke šerijatske temelje i pravila o kojima postoji konsezus muslimana kroz historiju, konsezus islamskih pravnih škola $\mathrm{i}$ islamske pravne misli.

Oni zaboravljaju da ovakvi kategorički i definitivni tekstovi jednostavno ne mogu biti u koliziji sa javnim koristima ljudi. Ovo može biti samo greška ili hipotetička pretpostavka, jer je općepoznato pravilo da definitivni, kategorički tekstovi nisu u koliziji i suprotnosti sa javnim koristima. Oni jednostavno ne mogu prepoznati šta je korist, jer su pod njenim izgovorom tražili dozvolu alkohola, prostitucije, kamate, zabranu posta, moratorij na dužnost hadža, izjednačavali brata i sestru u nasljedstvu, i sve pod izgovorom priskrbljivanja koristi od toga, iako je to u jednoj kritičkoj analizi lahko osporiti, posebno što se ovakvim stavom i sumnjom stavljaju iznad Uzvišenog Zakonodavca kao da znaju bolje od Njega šta je to korist za Njegova stvorenja koja je stvorio i podario im nebrojene blagodati...Uzvišeni kaže:

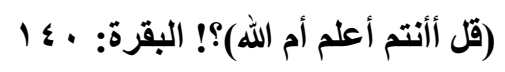

„Reci: "Znate li bolje vi ili Allah?!..." /140/2

Neki jednostavno ne razumiju šta je to korist, pa je definiraju kao: parcijalnu, osobnu, lokalnu, materijalnu, aktualnu, dunjalučku; dok je Šerijat definira općenito i kao spoj različitih: parcijalnu i opću, ličnu i društvenu, lokalnu i svjetsku, materijalnu i nematerijalnu, aktualnu i buduću, ovosvjetsku i eshatološku. Sve ove dimenzije koristi ne poznaje i ne razumije niko osim Uzvišenog Koji sve zna i

\footnotetext{
${ }^{1}$ Kur'an:5:33.

${ }^{2}$ Kur'an:2:140.
} 
Kojem ne ispada ispod znanja i kontrole ni jedna trunka na Zemlji i Nebesima.

Oni su idžtihadom ušli u vode gdje ljudski upliv i idžtihad nisu dozvoljeni. Realnost islamskog svijeta je da su ukinuli šerijatske propise i fiksirane kazne i šta je rezultat toga?! Jesu li muslimani sa savremenošću postali napredniji i razvijeniji $u$ društvenom ili ekonomskom ili bilo kojem drugom smislu? Ostali su u grupi onih koji se nazivaju „treći svijet“, svijet koji je zaostao iza svjetskog napretka.

Saudijska Arabija je bila primjer anarhije i nesigurnosti za život i imetak. Hadžije koje su dolazile svake godine iz čitavog svijeta bili su meta bandi koje su ih presretale, pljačkale, pa čak i ubijale. Za one koji su išli na hadž i na umru govorilo se unaprijed da su izgubljeni, a kada bi se takav vratio govorili su za njega da se nanovo rodio:

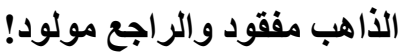

Onaj ko ide izgubljen je, a onaj koji se vratio nanovo se rodio.

Međutim, kada se promijenila vlast koja je počela suditi po Šerijatu i sprovoditi fiksirane kazne, stanje se korjenito promijenilo i prolazili su mjeseci bez ijednog razbojničkog napada ili kriminalnog slučaja. Istinska vrijednost i korist je da se ljudi pokoravaju Uzvišenom i da su svjesni da ih On i Njegovi meleki motre u svakom trenu. A, On, Uzvišeni nije ništa propisao ljudima osim koristi za njih i hajra, shvatili oni to ili ne. Uzvišeni je milostiviji prema njima od rođenih roditelja i zna bolje šta je korist za njih čak i od njih samih. Uzvišeni veli:

\section{(ألا يعلم من خلق وهواللطيف الخبير) الملك: ؛ 1 ـ}

A kako i ne bi znao Onaj Koji stvara, Onaj Koji sve potanko zna, Koji je o svemu potanko obaviješten. $/ 14 \AA^{ß}$

Osnova za ibadet je, što se tiče obveznika, da ga doktrinarno prihvata i ne obzire se na druga značenja, dok je osnova kod običaja, odnosno građanskog prava da se uzima u obzir značenje.

Iz doktrinarnog pristupa ibadetu razumijemo mudrost potčinjavanja i pokoravanja naredbama Uzvišenog, uzimanje Njega

\footnotetext{
${ }^{3}$ Kur'an:67:14.
} 
jedinog kao ibadetski cilj i Njegovo veličanje i obraćanje Njemu, a ovo ne upućuje na određeni efektivni uzrok iz kojeg se razumije određeni propis.

Osnova u običajima i civilnim ili građanskim djelima ili aktivnostima je da se uzima u obzir značenje kao i ciljevi i intencije.

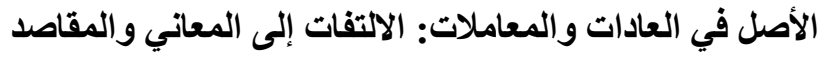

Zašto je rečeno da je temelj i osnova uzimanje u obzir ciljeva i intencija?

Muslimanski obveznik ili adresat المكلف uzima doktrinarno kao obavezu ili kao iskušenje kojem ne poznaje sve dimenzije i tajne, da bi kao vjernik na koncu samo rekao: čujem i pokoravam se, i to je vjera... A u ibadetima postoje mudrosti i tajne koje poznaje samo Mudri Zakonodavac. Naravno da to sve ne znači kako je princip temelj ibadeta, doktrinarni pristup u tome, bez da se osvrće i uzima $u$ obzir značenja, ciljeve i intencije, odnosno da su ibadeti lišeni toga potpuno, što nikako nije tačno, jer sve što je Uzvišeni i Mudri Zakonodavac propisao od obredoslovlja i civilnih građanskih radnji i djela, sve je to propisano s razlogom i u tome ima neka mudrost $\mathrm{i}$ korist za čovjeka, spoznao to neko ili mu promaklo, razumio to ili ne razumio. I ništa Uzvišeni i Mudri Zakonodavac nije propisao iz igre i zabave bez dubokog razloga, bez svrhe, logike i koristi. Međutim, sve te mudrosti, ciljevi i intencije nisu poznate ali se za njih zna uopćeno iz obavještenja Uzvišenog Mudrog Zakonodavca kroz kur'anske ajete koji otkrivaju generalne, općenite mudrosti, razloge, ciljeve i intencije u pojedinim ibadetskim normama:

(وأقم الصلاة، إن الصلاة تنهى عن الفحشاء والمنكر، ولذكر الله أكبر) العنكبوت: ه ؛ .

...i obavljaj namaz - namaz, zaista, odvraća od razvrata i od svega što je ružno; a Allahovo spominjanje vas veće je od vašeg spominjanja Njega!..." /45/

$$
\text { (خذ من أموالهم صدقة تطهر هم وتزكيهم بها) التوبة: ب ـ 1. }
$$

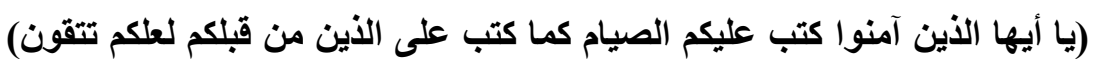

\footnotetext{
${ }^{4}$ Kur'an:29:45.
} 
"Uzmi od dobara njihovih zekat, da ih njime očistiš $i$ blagoslovljenim ih učiniš..." /103/"O vjernici! Propisuje vam se post, kao što je propisan onima prije vas, da biste bogobojazni bili." /183/

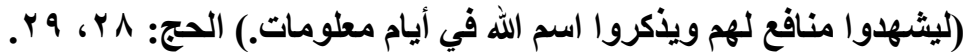

"Da bi svjedoci bili koristi svojih i da bi ime Allahovo spominjali u danima poznatim $\ldots / 28 /^{6}$

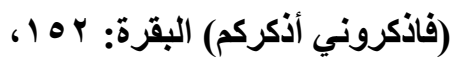

"Pa, sjećajte se vi Mene, i Ja ću se vas sjetiti..."/152/7

$$
\text { (ألا بذكر الله تطمئن القلوب) الرعد: ^^. }
$$

... - a srca se, doista, kad se Allah spomene, smiruju. $128{ }^{8}$

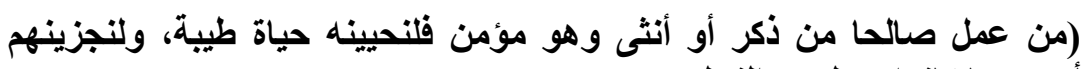

أجر هم بأحسن ما كانوا يعملون) النحل.97 :

"Onome ko čini dobro, bio muškarac ili žena, a vjernik je, Mi ćemo dati da proživi lijep život i doista ćemo ih nagraditi boljom nagradom nego što su zaslužili." /97/9

Prema tome, spoznaja mudrosti i općenite koristi u ibadetima je moguća i realna, ali ono što se ne zna i ne može spoznati jesu sve pojedinačne tajne i mudrosti u raznim parcijalnim dijelovima ibadeta.

Ako bismo izanalizirali namaz, vidjeli bismo da ne možemo spoznati mudrost, parcijalnu korist iz mnogih njegovih dijelova, niti možemo odgovoriti zadovoljavajućim ograničenim i preciznim odgovorom na sljedeća pitanja npr.:

Zašto je propisano baš pet, a ne tri ili sedam dnevnih namaza?

Zašto su tačno u ovim vremenima, a ne prije ili poslije ili raspoređena na neki drugi način?

Zašto sabah ima samo dva rekjata, a ne četiri kao podne? Ili zašto akšam ima tri, a jacija četiri i sl.?

\footnotetext{
${ }^{5}$ Kur'an:2:103 i 183.

${ }^{6}$ Kur'an:22:28-29.

${ }^{7}$ Kur'an:2:152.

${ }^{8}$ Kur'an:13:28.

${ }^{9}$ Kur'an:16:97.
} 
Zašto se baš u nekima uči naglas, a u nekima u sebi? Zašto nije obratno?

Zašto je ruku' jednom, a sedžda dvaput?

Zašto se na svakom rekjatu uči Fatiha, a nije recimo sura Ihlas? Itd.?

Ima jedna opća mudrost koju znamo, a ta je da nas Uzvišeni i Mudri Zakonodavac iskušava sa nečim čemu ne znamo sve dimenzije i tajne, da bi se nesporno napravila razlika između onoga ko slijedi Allahovog Poslanika i onoga ko ne slijedi, i između onoga ko slijedi svoju pamet i svoje strasti od onoga ko slijedi naredbe svoga Gospodara.

Kada bi se sve moglo objasniti i kada bi sve podlijegalo razumu, onda bi čovjek bio pokoran njemu - razumu, a ne Uzvišenom Mudrom Gospodaru Koji ga je stvorio i usavršio. Pravo vjerovanje i prava pokornost se izražava u slučaju kada se čovjeku naredi nešto u čemu on ne vidi i ne raspoznaje korist sebi, pa se on iz vjerskih pobuda potčini naredbi Uzvišenog i kaže: Čuli smo i pokoravamo se!

Osnova je u ibadetu, da se čini i prakticira potčinjavanjem Allahovoj naredbi koja se uzima kao Božije pravo i izvršava kao zahvala na Njegovim blagodatima koje se ne mogu osporiti. Rezultat ovog potčinjavanja se ne mora vidjeti na materijalnom planu i priskrbljivanju koristi kod uobičajenog ljudskog života, niti je nužno da se raspozna ta mudrost od ograničenog ljudskog razuma i pameti. Osnova je da je to vid iskušenja čovjeku u sistemu pokornosti svome Gospodaru i nema značenja $u$ tome da se spozna tajna u svakom parcijalnom dijelu, a konačno, rob Božiji je samo rob Božiji, a Gospodar je Gospodar. I najsretniji čovjek je onaj koji spozna svoju vrijednost u odnosu na svoga Gospodara.

Zbog toga je dovoljno čovjeku da spozna, uopćeno, da je Uzvišeni Gospodar neovisan o svim svjetovima, da nema potrebe ni za njegovim ibadetom i njegovom pokornošću, ne koristi mu pokornost pokornog, niti mu šteti nepokornost nepokornog i grešnog:

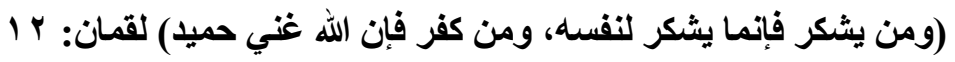


"... Ko je zahvalan, čini to u svoju korist, a ko je nezahvalan pa, Allah je, zaista, Neovisan i hvale Dostojan." /12/10

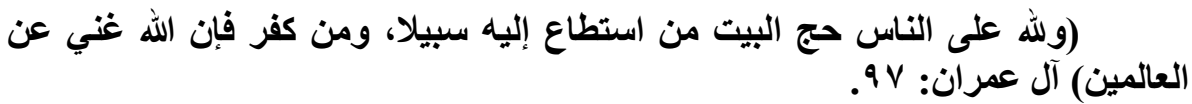

"... Hodočastiti Hram, radi Allaha, dužan je svako ko bude u mogućnosti do njega doći. A ko ne vjeruje - pa, Allah je, doista, neovisan o svjetovima!"/97/11

Dakle, Uzvišeni Allah je potpuno neovisan od svojih stvorenja, i kada Ga oni obožavaju i pokoravaju $\mathrm{Mu}$ se, onda to čine na način i sredstvima koji njima služe i koriste im u njihovom materijalnom i duhovnom životu; u životu pojedinca i društva, na ovom i budućem, eshatološkom svijetu. Na stranu što čovjek sa svojom ograničenošću sve to ne može da promotri i spozna kroz sve mudrosti i dobra koja mu njegov Gospodar kroz to nudi. Bila bi greška da tragamo za svakom mudrošću koja bi zadovoljila naš razum u svakom pojedinom parcijalnom dijelu ibadeta, pogotovo u ovom savremenom dobu materijalizma i koristoljubivosti.

Zalutali su oni koji su pokušavali razumjeti svaku mudrost, $\mathrm{u}$ svakom dijelu ibadeta, $\mathrm{i}$ onda kada im se ta mudrost nije ukazala $u$ pojedim pracijalnim dijelovima ibadeta, jednostavno su izgubili kompas vjere.

\section{Ibadet se izuzima od principa preferiranja koristi يستثى العبادات من تقديم المصلحة عليها}

Neka ulema, kao Gazali, prije njega njegov šejh ImamulHaramejn i neki drugi učenjaci, govrili su o općoj, javnoj koristi i njenom preferiranju nad nekategoričkim tekstom norme ili konsezusu izuzimaju ibadete i neke fiksirane odrednice u Šerijatu. Obrazloženje je u tome da se princip koristi u civilnim ili građanskim djelima i postupcima može primijeniti, ali ne i u ibadetu, iz razloga što su ibadeti prava Šerijata koja se ne znaju na drugi način osim putem Šerijata, dok prava obveznika spadaju u domen šerijatske politike i propisana su da bi im koristili. Koristi u ibadetu, kao što smo naveli,

\footnotetext{
${ }^{10}$ Kur'an:31:12.

${ }^{11}$ Kur'an:3:97.
} 
nisu poznate u svim dimenzijama, dok je korist $\mathrm{u}$ domenu šerijatske politike obveznika poznata i dokučiva razumom ili poznatim važećim običajima...

U domenu ibadeta koji nisu čisti ibadeti, nego imaju primjesu i drugih dimenzija, kao što je zekjat, uprkos statusa jednog od temeljnih ruknova islama, ipak nije čisti ibadet, kao što je namaz ili post, nego je ibadet sa značenjem i sadrža(van)jem jednog vida davanja poreza ili možda obratno, to je davanje - porez sa značenjem ibadeta. Prema tome, ovaj rukn islama sadrži dva elementa:

1. ibadet sa kojim se približava Uzvišenom Allahu i zbog toga se spominje uz namaz na 28 mjesta u Kur'anu;

2. materijalno pravo i obavezu koju je Uzvišeni Zakonodavac propisao kao obavezu u imetku bogatog da bi dio povratio siromahu i da bi se distribuirao kategorijama koje je Šerijat propisao.

Zbog toga, neka ulema uzima u obzir samo jedan element, dok se drugi okreću drugom; tako hanefijski učenjaci drže da je zekjat ibadet, a time postaje obavezan na obveznika (a on je onaj koji ispunjava uvjete obaveze kao što su punoljetstvo i pamet) čime su oslobodili maloljetnika i ludaka, makar imali milione i brojali se najbogatijima u društvu.

Sa druge strane, izrazita većina uleme (malikije, šafije, hanbelije) zekjat tretiraju kroz materijalno pravo i obavezu u imetku, tako da zekjat smatraju obavezom i u imetku maloljetnog ili umobolnog.

Međutim, ima i suprotan primjer da izrazita većina uleme smatra zekjat ibadetom, kad je u pitanju davanje protuvrijednosti i ne dozvoljavaju to, nego obavezuju na uzimanje i prikupljanje zekjata $\mathrm{u}$ naturi, pridržavajući se bukvalnog značenja norme o zekjatu. Na hanefijske učenjake uticalo je ovo drugo značenje i oni dozvoljavaju zekjat i u protuvrijednosti bez obzira o kojoj vrsti zekjata se radilo: zekjat na imetak ili zekatul-fitr, pošto je bitno pomoći sirotinju ili potrebnog, a to se postiže protuvrijednošću kao i naturalno, pa čak je protuvrijednost u mnogim slučajevima daleko pogodnija za primaoca zekjata od naturalne vrijednosti. 
Prema svemu tome, zekjat je dio ekonomskog i društvenog sistema islamske države. U savremenim trendovima razvoja fikhske znanosti moguće ga je svrstati u fikhske propise koji se bave islamskom ekonomijom prije nego da se stavlja u domen čistog ibadeta.

\section{Zaključak}

Islam baštini koncept umjerenosti koja se očituje u svim segmentima islamske misli, od morala i etike do društvenopravnog sistema. Manifestacija koncepta umjerenosti obuhvata sve oblasti sistema islamskog života i islamske vjere, tako da se primjećuje u ideji i praksi; u ibadetu i obredoslovlju, u odgoju i obrazovanju; u pravnom i političkom sistemu, kao i u svim drugim oblastima života.

Islam daje srednji umjereni put u vjeri, razlikujući se od budizma u pogledu na moral i moralne principe, ali razlikujući se i od vjerskih sistema koji traže potpunu posvećenost asketizmu zanemarivanjem ovosvjetskih vrijednosti kao što je evidentno u ideji kršćanskog asketizma i sveštenstva.

Umjereni put u šerijatskom zakonodavstvu i društvenom pogledu ogleda se u ravnoteži i balansu, između slobode pojedinca i prava društva, naslanjajući se na logičko i doktrinarno razumijevanje parcijalnih šerijatskih tekstova, a uzimanjem u obzir općih intencija i ciljeva Šerijata.

Tri su škole u savremenim fikhskim trendovima po pitanju ciljeva i intencija Šerijata koje odražavaju i spomenute krajnosti, ali se ujedno i jasno ocrtava i preferiranost škole srednjeg, umjerenog puta, koja svojim konceptom umjerenosti stoji između dvije krajnosti novih bukvalista, formalista kojima je „sveto” doslovno, bukvalno značenje teksta norme i novih mua'ttila ili reformista kojima ništa nije "sveto" i koji sve dovode u pitanje pa i „svetost" definitivnih, konačnih, kategoričkih kur'anskih normi. 


\section{Literatura:}

1. Korkut Besim, Kur'an s prevodom, (Štamparija kralja Fehda, S. Arabija, Medina, 1412.h),

2. Abdul-Kerim Zejdan, El-Vedžizu fi usulil-fiqh (Kompendijum metodologije islamske jurisprudencije), (Muessesetur-risale, 1987),

3. Ahmed Er-Rejsuni, Nazarijetul-mekasid indel-imam Eš-Šatibi, el-ma'hedila'lemi lilfikril-islami, 1992.

4. Bedrud-din El-A'jni, U'mdetul-kari'i šerh Sahihul-Buhari (Temelj čitaocu, komentar Buharijeve Vjerodostojne zbirke hadisa), (Darul-fikr, Bejrut),

5. Dželalud-din Es-Sujuti El-Ešbahu ven-nezairu fi kava'idi ve furu'i fikhiššafi’ijjeti (Sličnosti i uporednosti u metodologiji i pravu šafijske pravne škole), (Darul-kutubil-i'lmijje, Bejrut, Libanon 1993),

6. Ebu Ishak Ibrahim b. Musa Eš-Šatibi, El-Muvafekatu fi usulišs-šeri'ah (Sklad u temeljima islamskog prava), (Darul-ma'rife, bez godine izdanja),

7. Ibn Hadžer El-A'skalani, Fethul-Bari bišerh Sahihul-Buhari (Pomoć Stvoritelja kod komentara Buharijeve Vjerodostojne zbirke hadisa), (Darur-rejjan litturas, Kairo, 1987),

8. Ibnu Nudžejm El-Ešbahu ven-nezairu ala mezhebi Ebi Hanifeten-Nu'man (Sličnosti i uporednosti pravne škole Ebu Hanife En-Nu'mana), (Darul-kutubili'lmijje, Bejrut, 1993),

9. Ibnul-Kajjim El-Dževzijje, I'alamul-muvekki'in an rabbil-alemin, (Darulkutubil-i'lmijje, 1991, Bejrut),

10. Jusuf El-Karadavi, Dirasetun fi fikhi mekasidiš-Šeri'a bejnel-mekasid elkullijje ven-nususil-džuzijje, Daruš-šuruk, 2005.

11. Jusuf Hamid El-A'lim, El-Mekasidul-a'mme liš-šeri'atil-islamijje, El-ma'hedula'lemi lilfikril-islami, 1981.

12. Kitabul-ummeti, Katar; dr. Nurud-din El-Hadimi, El-idžtihadul-mekasidi, hudžijjetuhu... davabituhu... medžalatuhu, 1419.

13. Mekasiduš-šeri'ati ve kadajal-a'sr (Ciljevi, intencije u Šerijatu i savremena pitanja) „Centar za izučavanje ciljeva i intencija Šerijata"

14. Muhammed b. Ali Eš-Ševkani, Iršadul-fuhul ila tahkiki-lhakki min ilmil-usul (Vodič znamenitima u postizanju istine u metodologiji islamske jurisprudencije), )Darul-kutubil-i'lmijje, 1994),

15. Muhammed Ebu Zehre, Usulul-fiqh (Metodologija islamske jurisprudencije), (Darul-fikril- Arebi),

16. Muhammed Et-Tahir, Usulul-fiqh (Metodologija islamske jurisprudencije), (Dar Bu Selame, Tunis), 
17. Muhammed Nesib Er-Rifa'i, Tejsirul-a'lijjil-kadir lihtisari tefsir Ibni Kesir, (Olakšavanje Uzvišenog, Moćnog u sažetku tefsira Ibni Kesira), (Bejrut, 1978).

18. Muhammed Revas Kal'atdži, dr. Hamid Sadik Kanibi, Mu'džemu lugatilfukahai, a'rebi-inklizi (Arapsko-engleska enciklopedija šerijatsko-pravne terminologije), (Darun-nefais, 1985),.

19. Muhammed Sidki b. Ahmed El-Burno „El-Vedžizu fi idahi kavai’dil-fikhilkullijjje” (Kompendijum pojašnjenja općih fikhskih pravila), (Mektebetulme'arif, Rijad, 1989),

20. Mustafa Ahmed Ez-Zerka, El-Medhalul-fikhil-a'mm (Opći uvod u islamsko pravo), (Darul-fikr, 1968),

21. Mustafa Ahmed Ez-Zerka, El-Medhalul-fikhil-a'mm (Opći uvod u islamsko pravo), (Darul-fikr, 1968),

22. Sejfud-Din Ebul-Hasen, poznat kao El-Amidi, El-Ihkjam fi usulil-ahkjam (Savršenstvo u temeljima pravnih propisa), (Darul-kitabil-Arebi, 1984),

23. Sejjid Sabik, Fikhus-sunne (Islamsko pravo u sunnetu), (Darul-fikr, Bejrut, 1977),

24. Vehbe Ez-Zuhajli, Usulul-fiqhil-islami (Metodologija islamske jurisprudencije), (Darul-fikr, 1986), 
Muharem Stulanovic $\mathrm{Ph} \mathrm{D}$

\section{CONCEPT OF MODERATION IN ISLAM AND ITS MANIFESTATIONS IN FIQH}

\section{SUMMARY}

It is evident that in Islam there is a concept of moderation, which is reflected in all aspects of Islamic thought, from morals and ethics to social and legal systems. Man as a created and limited being is unable to establish an absolute balance in his worldly life because of his mental and physical weakness, his personal drive, passion and desires, objective and subjective influences from society, family, politics, nation, race, geographical origin, customs, etc. All systems which are created by man bear also his human flaws which is also confirmed by the method of historical induction in reading the chapters from history. Opossite to this, we see a harmony and precision in God's creation and in His religion which He sent as a living system and the program of life.

Moderate way in Sharia law and its view on society is reflected in the balance between individual liberty and the rights of society. It is based upon understanding of the partial Shari'ah texts in the light of general intentions of the Sharia to whom it will not contradict or be independent of them.

The moderate school in Islamic law proclaims that Sharia contains all that is grace for the people, and that it facilitates and helps humans in life. Islamic scholar - mujtahid must have a scientific, intellectual, moral, physical and other qualities to be able to properly evaluate Sharia regulations, looking at the legal norms from the Quran and Hadith from the viewpoint of the intentions and objectives of the Shari'ah.

\section{Keywords}

The concept of moderation الوسطية, the Islamic legal thought, partial Sharia texts, mujtahid, New formalists, New mua'ttile or reformists, moderate school, the legal norm, the effective cause of the regulation ... 
الأستاذ الدكتور محرم شتولانوفيتش

مفهوم الوسطية في الإسلام ومظاهرها في الفقه الإسلامي

\section{خلاصة البحث}

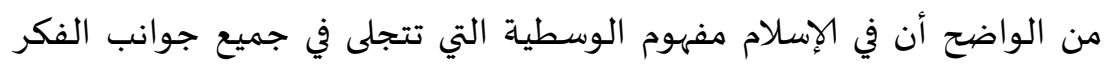

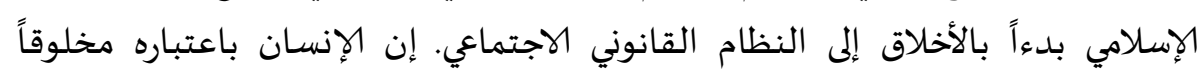

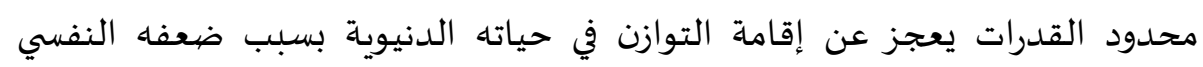

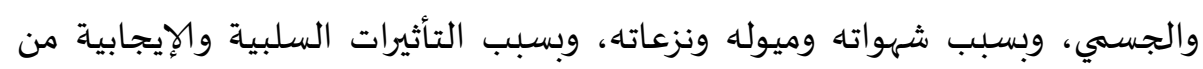

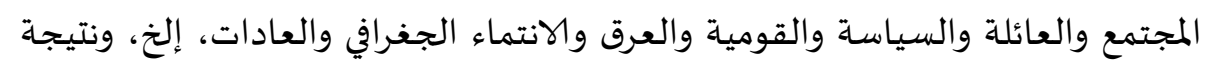

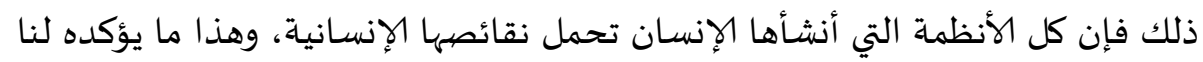

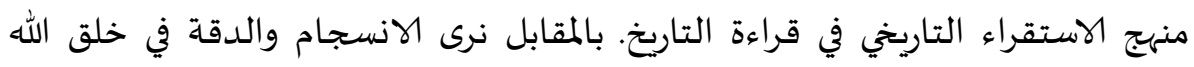

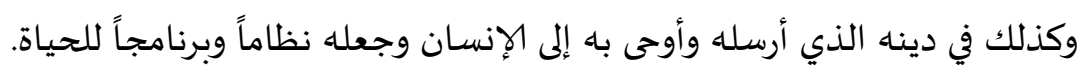

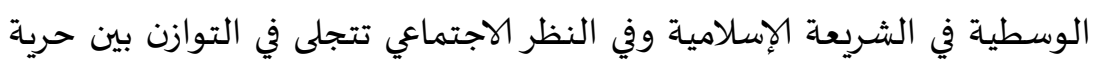

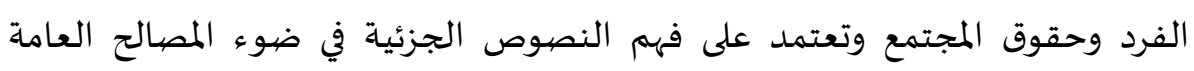
ومقاصد الشريعة التي لن تعارضها أو تستقل عنها.

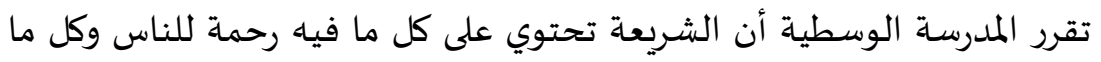

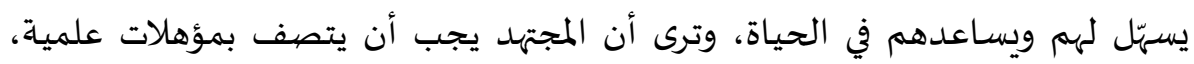

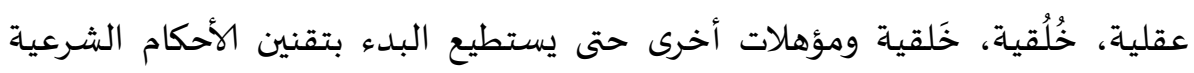

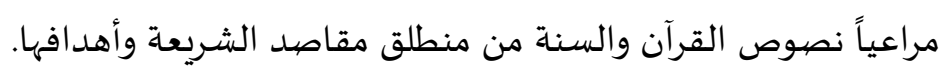

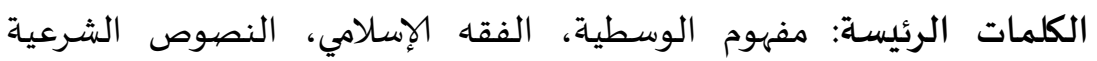

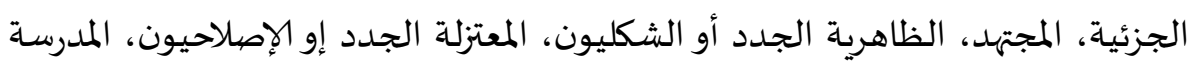

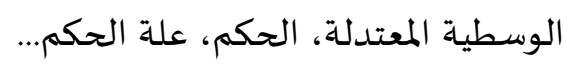

